\title{
Uma Panorâmica Geral no Planeta Jurídico- Positivistar Kelsen e os Outros
}

\author{
Guilherme Camargo Massaúl
}

1 Introduçẫo. 2 Uma Panorâmica Geral no Planeta Jurídico-Positivista. 2.1 As Principais Visôes Juŕdicas 2,2 As Concepçōes de Ross e de Hart 2.2.1 Ross 2.2.2 Hart. 3 Kelsen e Controvérsia 3.1 Kelsen Versus Cossio em Cabral de Moncada. 3.2 Castanheira Neves: Seu Diálogo com Kelsen. 3,3 Kelsen em Ortega y Gasset 3.4 De Kelsen paraRoss 4 Conclusão Referências.

Resumo: O texto busca traçar o positivismo jurídico kelseniano de forma um pouco distinta da tradicional. Como o espaço da galáxia positivista é demasiado amplo para a sua total descrição, o ponto principal envolve a esfera jurídica, entāo, incontomavelmente, as teorias do Direito próximas ao pensamento de Kelsen. Justamente este aporte possibilitará o salto para comparar Kelsen com os outros autores. Logo, ter-se-á uma visão geral do positivismo jurídico e, após, o confronto do austríaco com os outros autores.

Palavras-chave: Filosofia do Direito. Kelsen. Outros Autores. Positivismo Jurídico. Teoria Pura do Direito.

Abstract: The text search delineates the legal positivism Kelsenian a little different from the traditional. As the positivist space of the galaxy is too wide for its full description, the key point involves the legal sphere the theories of law near the thought of Kelsen. Precisely this contribution will jump to the Kelsen compare with other authors. So, shall take an overview of legal positivism and after the confrontation with Kelsen the other authors.

Keywords: Kelsen. Legal Positivism. Other Authors. Philosophy of Law. Pure Theory of Law.

\section{Introdução}

Embora" a reflexẳo sobre o pensamento kelseniano seja uma temática muito explorada nas academias juridicas, tanto em âmbito brasileiro como mundial, a pretensão deste trabalho não reside no esgotamento bibliográfico, crítico nem

\footnotetext{
Professor; Doutorando pela Faculdade de Direito de Coimbra Portugal

" Texto escrito com as novas regras ortograficas da língua portuguesa que entraram em vigor em janeiro de 2009 .
} 
analítico; pelo contrário, constitui mais um quadro informativo com um percurso distinto do desenvolvimento temático corrente na bibliografia consultada. Além disso, a exposição realizada no desenvolvimento está calcada mais na visão/ interpretação kelseniana de alguns textos do autor. Tal opção foi motivada pela intenção de explorar a bibliografia pouco difundida sobre o tema.

A opção por não adentrar imediatamente no positivismo kelseniano ocorre pela necessidade de pré-compreensão de outras dinâmicas denominadas de positivistas. Isso tem implicaçôes em alguns confrontos realizados pelo autor, pelo menos no tangente ao esforço de defender sua Teoria Pura do Direito juntamente com as bases teóricas sustentadoras de sua concepção, como a diferença epistemológica entre o Sein e o Sollen. Além do mais, o período histórico antecessor do jurista revela a direção do desenvolvimento do pensamento humano e o caminho percorrido até culminar na doutrina da Teoria Pura. Por isso, a visão, mesmo parcial do espaço, possui um sentido fundamentante no reconhecimento de (prováveis) detalhes do pensamento kelseniano, pois se pressupôe o seu conhecimento pelos dos autores e doutrinas clássicas. Isso revela o desenvolvimento das visōes teóricas passadas e das presentes, além de constituir o cenário típico da movimen. tação positivista.

Porém, o espaço da galáxia positivista é demasiado amplo para a sua total descrição. Como o ponto principal envolve a esfera jurídica, entao, incontomavelmente, as teorias do Direito próximas ao pensamento de Kelsen e aquelas possuidoras de traços positivistas têm espaço no planeta jurídicopositivista. Assim, nâo poderiam ser ignoradas como Die Zurückführung des Rechts auf "Tatsachen", Die Rechtssoziologie, Die Rechtstheorien des Neukantianismus (Der Dualismus von Sollen und Sein, Die konstitutive Funktion des Bewuâtsein, Unter dem Einfluâ der Marburger Schule und der Südwestdeutschen Schule e Die Reine Rechtslehre). Exige-se a abordagem das concepçôes de dois juristas importantes como Hart e Ross; eles, 
principalmente o último, elaboraram teorias jurídicas capazes de mostrar alguns contrapontos com o positivismo kelseniano, ou seja, elas servem de parâmetros em distintos ângulos de visão.

O tópico - Kelsen e Controvérsia - não possui o intuito, simplesmente, de estabelecer pontos de conflito entre o jurista e os demais pensadores; pelo contrário, é a exposição de debates de cunho esclarecedor de algumas percepções sobre a Teoria Pura e outras teorias. Ao convocar esses debates, objetivou-se a inclusão da forma dialética de expor as virtudes e os vícios das correntes expostas. Claramente, o intento está direcionado para a compreensão do pensamento do austríaco por meio das divergências doutrinárias. Isso demonstra os pontos fracos e fortes da Teoria Pura, além de estabelecer mais alguns pontos de contato com a sua lógica e a de seu autor. Na controvérsia, estão gravados os pontos de convergência e divergência do positivismo jurídico kelseniano diante das demais teorias sobre o Direito; porém, salienta-se a pontualidade dessas divergências, o que significa ali estarem postas exemplarmente algumas das diversas discordâncias decorrentes do embate de concepções. Portanto, o último tópico é um resumido espaço de uma perspectiva dialógica de diferenças teóricas entre os teóricos.

De fato, o principal objetivo é fornecer subsídios a mais para a tão explorada visão panorâmica positivista. Então, parte-se da base conhecida e inserem-se elementos de pouca evidência em outros focos de discussão. Por isso, o texto mostra a diferença na tentativa de estruturar e formar - de maneira näo exaustiva - um consenso em torno do positivismo kelseniano e da ciência do Direito.

\section{Uma Panorâmica Geral no Planeta Jurídico-Positivista}

O positivismo juridico, embora em crise, consiste, conceptualmente ainda, em uma teoria relevante ao estudo do Direito e sua filosofia. Mesmo com o abalo sofrido após a Segunda 
Guerra Mundial, ${ }^{2}$ o positivismo permanece no centro de muitas discussões, principalmente, quando defrontado com uma pressuposta noção de direito natural - que reduz a validade à justiça. Em outra perspectiva, encontra-se o realismo que vincula a validade à eficácia. Na busca de uma via entre o direito natural e o positivo, este último, com suas inúmeras variantes, se encontra fortemente atuante no seio do pensamento jurídico, principalmente como direito vigente ordenador de uma realidade social. ${ }^{3}$ Ainda como linha orientadora. para novas concepçốes que buscam manter distinçōes entre justiça, validade e eficácia. ${ }^{4}$ Isso implica muitas tentativas de distinguir entre ius e lex, seja na aplicação de esquemas hermenêuticos/interpretativos, seja $\mathrm{em}$ considerar valores ético-morais como jurídicos, isto é, qualquer outra manifestação que considere o Direito mais abrangente do que as referências contidas na lex. Cabe ressaltar alguns sentidos, dentre os inúmeros, do positivismo: posição prática; sociológico-pragmática; teorético-filosófica; histórico-psicológica ${ }^{5}$.

Essas correntes revelam a riqueza de pensamento produzida pela concepção geral positivista, além de denunciar a impossibilidade de reduzir o positivismo jurídico a uma única forma de manifestação, a kelseniana ou outra qualquer. Emerge daí a necessidade de direcionar algumas consideraçóes

\footnotetext{
2. SALDANHA, Nelson. Filosofia do direito Rio de Janeiro: Renovar: 1998. p. 182.

${ }^{3}$ SALDANHA, Filosofia do direito. p. 178.

4 REALE, Giovanni e ANTISERI, Dario. Histónia da Filosofia. v. 3. 7 ed. São Paulo; Paulus, 2005. p. 909 vide as distnçōes entre jusnaturalismo e realismo jundico p. $906-$ 909.

s Classificação de Eric Wolf apresentada em: SALDANHA, Filosofía do direito. p. 178. Para WELZEL, ó positivismo reduz a razâo a um carăter técnico-instrumental, que capta e interpreta as impressöes sensiveis (empíricas). $O$ valor do Direito é irrelevante, sendo decisivo somente aquilo que funciona como Direito, sem exceça alguma, e todo outro Direito nâo positivo é um contra-senso. O autor destaca o seguinte: é irrelevante o conteúdo conferido ao Direito positivo, podendo ser as idéias de um determinado ponto de vista, como as "idéias" fixas de um psicopata, como as idélas de homens geniais etc. WEL ZEL Hans. Introducción a la Filosofía del Derecho. Derecho Natural e Justicia Material. Trad. Felipe Gonzáles Vicen. Buenos Aires-Montevideo, IB de F. 2005. p. 248-249
} 
sobre essas correntes $e_{+}$também, sobre o pensamento característico de alguns autores positivistas para, justamente, situar, especificar e distinguir o pensamento de Kelsen no planeta positivista.

\subsection{As principais visões jurídicas}

O tratamento do Direito como uma ciência foi concepção pensada pela linha sociológica, que pretendeu elaborar normas jurídicas espelhadas em fenômenos naturais, sem a participação da vontade e ideais humanos. ${ }^{6}$ Sem dúvida, o método a ser empregado se assemelha ao das ciências sociais, com três operaçóes: a observação; a interpretação e a comparação. ${ }^{7}$ De início, a teoria do Direito do positivismo filosófico deseja reduzir o Direito ao próprio fato-do-ser, ou seja, reconduz o Direito ao fato, sendo o dever uma conseqüência do juízo sobre o ser. Na possibilidade de visualizar a teoria sociológica do Direito, num sentido rigoroso, parte-se da teoria das Gesellschaftswissenschaft. Assim, Ehrlich ${ }^{3}$ não

\footnotetext{
- PERELMAN, Chaim. Lógica jurídica. Trad. Vergínia K. Fupi. São Paulo: Martins Fontes, 1998. p. 94: LEVY-BRUHL, Henri. Sociologia do direito. Trad. Antonio de Pádua Danesi. 2. ed. São Paulo: Martins Fontes, 2000. p. 95-99.

${ }^{7}$ LÉVY-BRUHL, Sociologia do direito. p. 99-117.

\& A objeção fundamental, em termos da ciência do Direito, fende-se em dois fundamentos de distintas direçóes: o objeto e o método. Assim, pode-se considerar o Direito como norma, ou seja, como forma determinada de Sollens e como Soll-regel específica. Portanto, a ciência do Direito como uma normativa e dedutiva ciência dos Valores quer ensaiar a percepçäo do Direito como una parte da realidade social (fato ou fenômeno), cuja regularidade abrange o caminho indutivo e a explicaçáo causal. Nesse sentido, o Direito passa a ser uma Seinsregel de determinada conduta humana; então, a ciência jurídica se torna um madelo das ciêricícs naturais. A possibilidiade de ser uma ciência social esté na identificaçăo de condutas humanas diante do carâter social da vida em comum, das regras sociaís, das regras da vida jurídica ou regras jurídicas. Assim é possivel adjudicar para si a qualificação de ciência social ou sociologia, até mesmo a existencia da sociologia jurídica mas a sociologia do Direito, com seu objeto e método, é distinta da ciência do Direito.

Existe a tendência de distinguir entre a observaçâo e a forma de pensar, além de diferentes objetos entre elas. Na perspectiva da sociologia do Direito está implicado como o Homem age (Sein) e na perspectiva da cjência do Direito, como o Homem deve agir (Sollen), O conteúdo da norma é o que deve suceder, ao passo que o conteúdo da regra sucumbe ao que se deve pronunciar quanto ao que de fato sucedeu. Uma ciência juńdico-sociológica não pode pronunciar para $Q$ quê e dentro de que condiçōes uma pessoa ou categoria de pessoas esté juridicamente obrigada
} 
ou autorizada, mas meramente ater-se ao que determina o Homem, como deve agir ou deixar de agir, dentro de certas pressuposições de fato. Com isso, tal ciência só pode ser um juízo de fato, um juízo sobre o contexto calusal determinado por fenomenos e, tampouco, pode conter alguns juízos de valor a exemplo da biologia, da química ou da psicologia, como fato valorativo indiferente, pois o válido, nesse caso, é a associaçăo causal. Naturalmente, a análise do objeţo vai desembocar no exame e no esclarecimento da regularidade das condutas sociais do Homem. Logo, seriam alcançadas as regras de Direito por meio de condutas fáticas fornecidas por uma especial sociologia juridica, apresentada por uma categoria social do Sein. Daí se retira o conceito normativo do Direito, assim abrange o Direito como norma $e_{\text {, }}$ diante disso, precisa valer como uma categotia de Sollen.

Kelsen destaca a falta de clareza na Grundlegung der Rechtssoziologie da separação do valor e da observação da realidade, além de ressaltar a contrariedade de Ehrlich pelo fa to de a prática da Jurisprudenz querer estabelecer uma pura ciência teorética, baseada na abstraçăo dedutiva: tal atitude fara o Homem perder o contato com a realidade. O jurista sociologo acreditava que tal atitude estabeleceria uma grande contradiçăo perante toda a genuína ciência, pois com o método indutivo o observador do fato iria aprofundar 0 conhecimento da essencia do objeto. O cientista jurídico contesta a exclusividade do mêtodo indutivo como científico e ressalva o conhecimento científico pelo método dedutivo. Além disso, ele combate a aversăo ao enxágue abstrativo com a indicação do enxágue da isolada aparição concreta. Para o austríaco, está-se diante da visão de uma ciência do Direito ser como uma disciplina causal-explicativa e indutiva, sendo o Direito considerado como a regra da açäo geral do Homem, mas isso se colocaria em oposiçăo à Jurisprudenz normativa. O emprego da palavra regra é questionado incisivamente, pois a questão é saber se é Soll-regeln ou Sein-regeln. Para esclarecer esse duplo significado de regra, empregaram-se as noçôes de biologia: nessa ciência, não se procura averiguar como deve comportar-se determinado ser vivo dentro de determinadas condições ou quais sẫo seus direitos e obrigaçôes, mas como ele se comporta regularmente. Nesse sentido, pode a sociologia - contanto que seja uma ciencia do ser causal-explicativa procurar fazer a Seinsregeln da conduta humana equivaler-se à regra ou a lei da biologia. Então surge a questão: o Gewohnheitsrechr seria aceito por EHRLick como válido? Para responder a essa questâo, é necessário conhecer algumas palavras preliminares, tal como Kelsen desenvolve, Então, até esse momento, foram prociuradas regras para a aça de determinadas categorias (Ciência do Direito kelseniana), como o Judiciário ou outro orgão do Estado, mas a sociologia do Direito procura uma regra de ação em que todos os Homens se enquadrem. Nesse sentido, Ehrlich identifica as regras de ação de fato com cada dever-agir, isso acarretando uma saciologia particular, uma sociologia de órgăo estatal, e da identificaça do órgäo com o Estado surge o Estado sociológico. Porém, a ação geral humana nâo é a açâo do Homem em geral, se não uma ação particular do Homem indicativa de uma dereminada direção. A questầo está em diferenciar uma direção especifica das demais direçóes resultantes da ação humand:

As consequências do pensamento ehrlichiniano estão expressas no exame do órgão Estatal, instigador da oposiçáo da prática diante da teona, e da oposiçâo entre regra à ação do órgão Estatal e regra à ação de todos os Homens, alêm da oposiçăo do causal e do normativo, do Soin e do Sollen. Aqui o ponto está na procura de uma regra geral para todos os Homens agirem, na tentativa de formar uma Sein e SollRegeln. Essas regras, denominadas de Ordenamento, algumas inferiores e outras superiores, na Comunidade são pensadas como prescrições de dever até cumprir-se

Cadernos do PPG em Direito UFRGS, Forto Alegre, v. $6, n .7$ e 8, p. 421-462, 2007. 
essa ordem de obrigaçốes. Tais regras de indicação de tarefas de cientificidade, em contraposiçầ à Jurisprudenz, cujo fim é a obtenção do objetivo da Sociologia juñdica teórica, têm caráter prático e teốrico ao mesmo tempo.

O jurista custriaco transporta a análise para a questão das Rechissätzen. A Rechtssatz pode significar a expressão linguística para o dever jurídico, isto ê idêntico à Rechtsnorm; ou significar a expressão linguística para uma regra do acontecimento de fato, ou seja, possut igual significado da Rechtsregel no sentido do Sein. Para a diferenciaça entre Rechtssatz e Rechtsnorm năo é conveniente, contudo, se entender como Rechtsnorm o imperativo das condutas legítimas acerca de juizos e como Rechtssatz, uma outra formaçăo linguistica ligada num determinado Tatbestand, uma sêrie de nâo-direitos. Entäo a Rechtsnormé estatuida com o Rechtssatz, assim possa-se deixar identificar Rechtsnorm e Rechtssatz, nesse caso. $O$ jusfilossofo destaca a crença de Ehrlich em que o Direito e as relacoes jundicas, nos primórdios, eram fundamentados sem a generalidade dos Rechtssätze, sendo o Direito antigo identico a ordem interna da associaçao original. Tal ordem, segundo o austriaco, seria composta por uma soma de nomas ou de determinadas Seinsregeln de condutas dos membros. Para o Ehrlich do Direjto, as séries de condutas concretas entre os parentes, os pais e as cnanças e as relaçôtes com outros cläs significavarm Direito.

Séries de questionamentos feitos e respondidos pelo austráaco o levam a conctuir que mesmo essas relaçôes da ordem interna de associaçôes primitivas encon. travam-se baseadas na pressuposição da validade da Rechtssatz. Porém, năo como o exposto por meio dos códigos e das legislaçós modernas - divisor de épocas pois os membros da associação sabiam, antecipadamente, de suas obrigações e seus direitos, por isso, cumpram os contratos, uniam-se em casamento ou manifestavam condutas aptas a gerarem direitos e deveres. $O$ conceito ehrlichiana de Rechissatz no sentido da Rechisnorm compreende a Sollregel, pois as relações jurídicas, os negocios juńdicos podem estar dentro de pressuposição de Rechtsnorm ou de Rechissatz. Se o jurista concluir um contrato ou instituir um testamento, ele precisa de uma Rechtssatz existente, segundo a qual os contratos ou os testamențos são obrigatónos; logo, ela estabelece, com isso, o abstrato diante do concreto.

Segundo o austríaco, se dentro da Rechissatz está compreendido uma norma juńdica geral e obrigatória, entăo ê logicamente impossível pensar relaçöes jurídicas sem pressuposiçoes semelhantes à Rechtssätze. A terminologia de Ehllich apresenta um significado divergente com o habitual a ponto de apresentar "uma quase" teoria da noma, a estabelecer que a Rechtssatz não deve ser confundida com a Rechisnorm, pois aquela é a redação geral e obrigatóna de uma prescriça jurídica na lei ou num código. Diante dessa diferenciação, Kelsen destaca que tampouco pode se entender na Rechtssarz somente o aspecto gramatical da lei ou do codigo. 0 desenvolvimento da análise sobre a Grumdlegung ehrlichiana dá-se de forma enfática nas expressoes juridicas compositoras da possibilidade de entendimento teórico (científico). Os argumentos do custrica buscam evidenciar a falta de precisăo no emprego das expressoes na análise de periodos da Históna, além de buscar provar a inconsistência de situar o Seinstatsachen como objeto da ciência jurídica. Isso recai na visăo dos institutos jurídicos como fatos psicológioos ou fenômenos do mundo exterior, sendo suas nomas atribuídas pelo observador pois para ele (Ehrlich), o Direito e as relaçôes jurídicas são coisas pensadas, viventes na cabeça do Homem. Se assim fosse, destaca o austríaco, a Jurisprudent seria um campo especial da Psicologia.

O modo de observaçăo nâo conduz a ưn juizo Recht ou Unrecht, de um deve ser ou não ser, mas a um jufzo de pensado e agido, de ser ou de era. $\mathrm{O}$ conthecimento do 
considerava o simples regramento de relações idêntico à normatização; os acontecimentos não se encontram préescritos e, por isso, não são devidos. ${ }^{9}$ Outra dimensão desse aspecto fático está no marxismus, pois, para ele, o Direito se reduz ao simples reflexo da estrutura econônica da sociedade. Não se visualiza o Direito com seus próprios valores, mas como outra coisa situada na superestrutura, sendo sua ação baseada na economia. Portanto, o aspecto jurídico é reduzido aos fatos sociais, no primeiro caso, e aos dados econốmicos, no segundo, e será por eles condicionado.

O fato psicológico do querer também fundamenta uma das correntes positivistas; sob esta perspectiva, a norma é a expressâo de uma vontade que se consome à espera de outra. A sua particularidade encontra-se no reconhecimento recíproco - tanto psicológico quanto "habitual" - em uma comunidade de seres humanos capaz de compreender um

\footnotetext{
observador sociológico é wertfrei, como o da biologia. Assim, a distinçào da Soziologie para a Rechtswissenschaft (no sentido nomativo) é igualmente a distinção de uma historna religiosa para a Theologie A conlusäo, segundo Kelsen, está em näo saber dividir o modo de observação, ou seja, toma-se em consideração explicativa do esclarecimento do Sein sociológico e recaí, diretamente, no conceito normativo do Direito. Disso, porem, advém um importante resultado da investigaçäo da sociologia jurídica que é $\odot$ conhecimento imediato do "Tatsachen des Rechtes"; e nada mais pode ser entendido como regra baseada sobre um Tatsache como objeto de regulação, sendo, talvez, os fatos do Direito, objeto de regulaçáo justa. O modo de observação nâo conduz a um juízo Recht ou Unrecht, de um deve ser ou näo ser, mas a um juízo de pensado e agido, de ser ou de era, O conhecimento do observador sociologico $t$ wertfrel, como o da biologia. Assim, a distinçao da Soziologie para a Rechtswissenschaft (no sentido nomativo) é igualmente a distinçăo de uma histôria religiosa para a Theologie. A confusáo, segundo Kelsen, está em não saber dividir o modo de observação, ou seja, toma-se em consideraçâo explicativa do esclarecimento do Sein sociológico e recaí, diretamente, no conceito nomativo do Direito. Disso, porem, advem um importante resultado da investigação da sociologia juńdica que é o conhecimento imediato do "Tatsachen des Rechtes", e nada mals pode ser entendido como regra baseada sobre um Tatsache como abjeto de regulaçá, sendo, talvez, os fatos do Direito, objeto de regulação justa. Trechos baseados em: KELSEN, Hans. Eine Grundlegung der Rechtssoziologie. In: AsWP. Band. 39, Heft I. Tübingen: Paul Siebeck, 1914 p. 839-845.

9 ZIPPELUUS, Reinhold. Das Wesen des Rechts. Eine Einführing in die Rechisphilosophie. 3. Auflag. München! Beck, 1973. p. 12.

${ }^{10}$ ZIPPELUUS, Das Wesen des Rechts. p. 13; vide: WELZEL, Introducción a la Filosofia del Derecho. p. 257-271.
} 
respeito contínuo da segurança normativa. O Direito é constituído por meio do psíquico correspondente ou de outro suporte fático fixo de experiência ${ }^{11} \mathrm{~A}$ questão do aspecto fático ainda se encontra invocada noutra corrente, esta de grande importância para as concepçôes kelsenianas: a teoria neokantiana do Direito. Ela assume posição relevante na forma como a Reine Rechtslehre vai se posicionar diante do fato e do Direito; isso implica rigorosa diferenciaçāo entre Sollen (Vorschreiben) e Sein (Beschreiben).

A norma (Sollen) não possui um simples sentido descritivo, pois diferencia-se da verificação de como o Homem é de maneira regular. Ela deve indicar algum acontecimento, ou seja, estabelece afirmaçoós descritivas sobre o decorrer dos acontecimentos, as quais [afirmaçöes], inclusive, poderäo ser refutadas por meio de experiências distintas. A questâo prescritiva assume duas implicações: se por um lado apresentar-se-á com aparência de conduta social, por outro, o objetivo da prescrição normativa se aproximará de um valor desejado de conduta na realidade social. Significa perceber a possibilidade de alterar a conduta prescrita quando

\footnotetext{
"ZIPPELIUS, Das Wesen des Rechts. p. 14. O autor continua sua exposicão no sentido de indicar a necessidade de atualizaçăo do Direito na direçâo de um intersubjeriver Sinngehalte em que a maioria dos homens participarem numa coordenação comum de açöes humanas.

72. ZIPPELIUS deixa o seguinte exemplo, ,... daB der Richter in bestimmter Weise urteilen soll, selbst wenn man prophezeien kann, daß er im worliegenden Rechtsstreit tatsächlich anders ("falsch") entscheiden wird" In Das Wesen des Rechts. P. 15. WELZEL chama atença ao falar do neokantismo de STAMMLr do conceito e da idéia de Direito, sendo o primeiro constitutivo e a idéia apenas regulativa. In Introducción a la Filosofía del Derecho p. 252. Ainda para esse autor, a clência do Direito se constitui em uma ciência final, pois ela se calca na relação entre meio e fim, ao contrário das ciéncias da natureza que estão baseadas na relação causa e efeito. A ciência juridica limita-se à funça de sistematizar adequadamente o contetido oferecido pelo direito positivo, sem inserir qualquer especie de alteração ou acréscimo. Sob essas coordenadas pode se conhecer o Direito justo. Ai advem sua teona do Direto justo Como o Direito é um modo de pensamento - de um querer vinculante - ele estâ sob a exigência da justeza. Porém, essa idêia está ligada a unidade de consciência; assirn uma proposição jurídica será justa se não contraditar com o conjunto de pensáveis "quereres juridicos." LARENZ, Karl Metodología da ciencia do direito. 3 ed. Trad. José Lamego Lisboa: Fundação Calouste Gulbenkian, 1997. p. 117-121.
} 
esta entra em contradição com a experiência. No entanto, a prescriçâo pode persistir diante de conduta social diversa e poderá ser atribuída uma sanção para tentar motivar o respeito à prescrição normativa. Assim, a apresentação prescritiva da norma nâo pode perder seu fundamento de validade para năo infringir a ordem. ${ }^{13}$

Com outro ângulo de visão, encontram-se as noçóes da expectativa ${ }^{14}$ cognitiva e da normativa $^{15}$ ao se enquadrarem nessa dicotomia neokantiana. Destarte, pode-se traçar a seguinte distinção: a expectativa cognitiva versa sobre a realidade e experimenta ajustar a ela todo caso de frustração da expectativa. Para a expectativa normativa vale o contrário; ela não pode ignorar se alguém transgrediu/desapontou a expectativa, ou seja, ela não pode ajustar a transgressão à realidade. Salienta-se, novamente, que a norma jurídica nẩo contém enunciados descritivos, mas prescritivos. $O$ conjunto do ordenamento jurídico é reduzido à proposição de dever ser. Isso tem validade para norma primária (que regra as zwischenmenschlichen Verhaltens) e para a norma secundária (sanção de Vollstreckungszwang oder Strafe) dispostas para o caso. Assím, proposição dever ser está fundamentada em outra proposição de dever ser, como num circuito fechado, por isso que as variantes da filosofia do direito neokantiano estão de acordo. ${ }^{16}$

\footnotetext{
13 ZIPPELIUS, Das Wesen des Rechts, p. 15-16.

${ }^{14}$ Para ZIPPELIUS, a palavra expectativa pode ocultar sentidos diversos daqueles esperados. In. Das Wesen des Rechts. p. 17. Para Luhmann, as estruturas possuem um recorte mais delimitado das possibilidades, delimitaçao eferuada pelas expectativas (as expectativas sâo fáticas - p. 57). Mas por elas serem enganosas em relaçao à complexidade do mundo, o sisterna das instituicoes trabalha com a perspectiva do desapontamento Por isso, o desapontamento decorre de eventual surpresa advinda da complexidade do mundo. LUHMANN, Niklas. Sociologia do direto I Trad Gustavo Bayer. Rio de Janeiro Tempo Brasileiro, 1983 , p 55.

${ }^{15}$ A diferença entre a expectativa cognitiva e a nommativa consiste, resumidamente, em a primeira diz respelto a adaptação da expectativa desapontada à realidade desapontante, a segunda versa sobre a sustentaça da expectativa, no intuito de contrapor se à realidade desapontante LUHMANN, Sociologia do direito I p. 56 , para maiores informacóes sobre essas expectativas p. 5366 . Em relacăo ao conceito de norma baseada numa expectativa (fatica) vide LUHMANN, Niklas. Das Recht der Gesellschaft. Frankfurt am Main: Suhrkamp, 1995. p. 32.

ZIPPELIUS, Das Wesen des Rechts. p. 16-18, REALE, Miguel. Fundamentos do direito. 3. ed Sắ Palulo: RT 1998 p. 2326.
} 
Ainda no trajeto proposto, abre-se a possibilidade de considerar a função constitutiva da consciência dentro da visão neokantiana. O fundamento está na teoria do conhecimento e na metodologia do dualismo: ordem e unidade no mundo apresentado e não pretendido pelo conhecimento, mas gerado por meio do pensamento e resultado de uma síntese. Assim, o pensamento projeta a lei e o contexto, além de constituir o objeto do conhecimento. Outra questấo essencial está na metodologia, ao transportar o ponto de vista copernicano à criaçấo da seleta cientificidade isolada da atividade, ou seja, da consciência. $O$ produto da síntese categorial é resultante da realidade, ao se expressar na teoria do conhecimento - um produto formado do conceito da ciência cultural. Diante disso, é possível entrar na zona de influência da Marburger Schule. Essa escola fílosófica concentra-se na função condicionada e sintética da consciência, sendo ela constituídora do objeto do conhecimento.

Na norma que determina a relação humana existe a diferença entre a norma jurídica e a regra advinda do costume; no entanto, existem características gerais entre elas. Por isso, faz-se necessário criar características identificadoras das normas jurídicas com o objetivo de diferenciá-las das outras espécies, por exemplo, das costumeiras. Dessa maneira, a filosofia do Direito deve interpelar o conceito de Direito para proporcionar a determinação dos objetos do conhecimento a fim de centralizar a realidade jurídica no ato de demarcação das normas de Direito de outras normas, sendo o conceito de direito constitutivo (com as formas de pensar permanente, a evitar a arbitrariedade e a injustiça ${ }^{17}$ - a vontade apresenta alguma coisa a ser realizada no futuro assim as normas jurídicas ordenam a vida em comum do Homem. Logo, a consciência coopera constitutivamente na formação e na delimitação do conceito geral. Critica-se o conceito de coisa bem como o conceito de Direito por não serem puros, mas conceitos $a$ priori, ao mostrar as reflexões prévias do sujeito. ${ }^{18}$

\footnotetext{
17 WELZEL, Introducción a la Filosofía del Derecho, p. 252-253.

ZIPPELUS, Das Wesen des Rechts. P. 18-20; REALE, Fundamentos do direito p. 138 141 .
}

Cademos do PFG em Direito UFRGS, Porto Alegre, v. 6, n. 7 e 8, p. 421-462, 2007. 
Outra escola a exercer influência na perspectiva neokantiana é a Südwestdeutschen Schule, ao partilhar concepção e método próprios. A maneira da livre-valoração e a generalizada da observaçẫo fornecem, como objeto do conhecimento, a lei natural num constante regresso à realidade contextualizada. A partir de entăo, mostra-se uma corrente cońtra o formalismo metódico da escola anterior, ao renunciar à validade de normas injustas. Ademais, se alcança uma idéia de Direito natural de conteúdo variável ${ }^{19}$ Isso implica a diferenciação da norma jurídica das demaís normas sociais, pois a primeira tem um caráter específico de valor, um sentido para realizar, diga-se: a justiça. Essa visâo admite normas que não aspirem à justiça, porém elas carecerão da natureza geral do Direito, podendo-lhes ser recusada a aplicação por serem injustas (não-jurídicas). ${ }^{20}$ A questão jurídica está circunscrita no justo e injusto, como leciona Radbruch, ao negar validade às normas injustas e nocivas ao bem comum ${ }^{21}$ Por fim, o esforço neokantiano destaca-se pela tentativa de deixar intacta a estrutura do conceito de Direito do estrito positivismo, sendo considerada uma teoria complementar ao inserir componente de "irrealidade", de "ideal", no conceito jurídico positivo. ${ }^{22}$.

Com o foco delimitado em Kelsen, a incursão resumida aos/nos dois autores seguintes possui o condão de estabelecer duas janelas diferenciadoras em face do horizonte kelseniano. Esses dois autores, conjuntamente com Kelsen, são oriundos da mesma tradiçăo intelectual, nem por isso eles deixam demonstrar de entre $\mathrm{si}_{\text {, }}$ pontos de divergências. A questão principal, neste momento, é diferenciar o positivismo

\footnotetext{
19 WELZEL, Introducción a la Filosofía del Derecho. p. 253.

20 ZIPPELIUS, Das Wesen des Rechts. p. $20-21$.

2 RADBRUCH, Gustav. Filosofia do dirello. Trad L. Cabral de Moncada. 6. ed. Colmbra: Arménio Amado, 1997. p. 417.

2z WELZEL, Introducción a la Filosofia del Derecho. p. 256-257; LARENZ, Metodologia da ciência do direito p. 125-138. Para uma abordagem do pensamento de RaDbruch vide: KAUFMANN, Arthur Filosofia do direito. Trad. António Ulisses Cortês. Lisboa: Fundação Calouste Gulbenkian, 2004 p. 62-67.
} 
empirista e o analítico, do aquele idealista. Nesse talante, buscar-se-á uma visão abrangente do pensamento de dois autores ligados ao patrimônio intelectual do positivismo, o que implica o vínculo com o kelsenianismo sendo mais um fato evidenciador da existência de diversas correntes positivistas.

2.2 As concepções de Ross e Hart ${ }^{23}$

A preocupação deste tópico é uma apresentaçāo dogmática dessas duas personagens do pensamento jurídico. A pretensão não é colocar algum deles no fogo cruzado das críticas nem mesmo construir estratégias para criticar o positivismo kelseniano, mas somente buscar compreender os respectivos pensamentos para enriquecer a paisagem das estruturas/estratégias positivistas de Kelsen: nada além de mostrar pontos de partida e de chegada distintos do conceito de Direito.

\subsubsection{Ross}

A proposta filosófica de Alf Ross reside no sentido da interpretaçấo do conceito de Direito válido. $O$ ponto-chave desencadeia uma sequência de significados norteadores, a começar pelo conceito de regra jurídica que clama pelo gênero denominado de proposiçấo diretiva. As proposições diretivas exercem influência no comportamento, porém não possuem o escopo informativo. Para guiar o comportamento humano de modo pré-estabelecido, encontram-se as espécies de proposição diretiva, as regras jurídicas. ${ }^{24}$ Portanto,

\footnotetext{
Esse tópico tem como base as consideraçōes de BARZOTTO Luis Fernando. O Positivismo Jundico Contemporâneo, uma introduçăo a Kelsen, Ross e Hart. 2, ed. Porto Alegre Livraria do Advogado, 2007 .

2z $O$ exemplo fornectdo pelo jusflósofo é a analogia da regra juídica com a regra de xadrez. A imagem desenhada é a seguinte dois jogadores de xadrez e un terceiro a observar o jogo. A hipótese de o observador năo conhecer as regras do jogo, faz com que os movimentos realizados pelos jogadores näo possuam nenhum sentido. Assim, as jogadas, para o observador, serão arbitránias e sem propósito. No entanto, se o observador conkecer as regras do jogo, cada movimento terá um significado e ele poderâ compreender as jogadas e o jogo. BARZOTTO, O Positivismo Juridico Contemporâneo p. 68.
} 
as regras jurídicas, sob determinado ângulo, são captadas pelos sentidos, com a possibilidade de serem explicadas por leịs baseadas nas noções fisiológicas. Porém, a questáo jurídica não é estancada nesse momento; para entendê-la é preciso convocar regras jurídicas, pois a dimensão das leis casuais não satisfaz as exigências das regras jurídicas. A questáo focaliza-se nos significados dos fenômenos sociais do Direito, portanto, deve pressupor as regras jurídicas. Elas são diferenciadas das técnicas, sendo as juridicas diretivas ao indicarem diretamente a conduta a ser observada. Quando não cumpridas/transgredidas, resultam em uma sanção ou protesto, ao passo que as técnicas indicam condutasmeios para se atingir uma determinada finalidade e quando não observadas, o objetivo desejado não se cumpre ${ }^{25}$

Após conhecidos os traços das regras jurídicas, é fundamental estabelecer os critérios de identificação. Para tal, devern ser considerados dois modelos pré-compreensivos de identificação. O primeiro, denominado "condutivista", consiste na observação dos comportamentos. No entanto, a observação não é suficiente para identificar as regras ao nẫo permitir diferenciar as regras das regularidades de conduta, ocasionadas pelo costume, pelo hábito, pela técnica. Assim, nem sempre atinge a medida diferenciadora entre a regra jurídica (do permitido e proibido) e comportamentos habituais. O segundo, conhecido como "formalista", limita-se a consultar os documentos contentores das regras jurídicas prescritas. Para Ross, tal modelo é insuficiente devido à dificuldade de conhecer as regras praticadas pelos membros sociais. Depois de verificada a insuficiência desses dois modelos, o pensador propôs duas regras: 1) para contrariar a insuficiência do formalismo, ele estabelece que a regra deve ser efetiva e ser constatada pela observação; 2) do mesmo modo, em oposiçắo ao condutivismo, a obrigatoniedade social da regra deve estar calcada na experiência emocional.

25 BARZOTTO O Positivismo Jurídico Contemporâneo. p. 68. 
Portanto, a validade ${ }^{26}$ da regra será auferida pela efetividade do comportamento movido pelo sentimento de obrigatoriedade social. Nota-se a interdependência das regras com os fenômenos; sem essa ligaçăo năo se pode determinar a conduta adequada às regras jurídicas. Então, a regra jurídica só tem sentido, de fato, quando é empregada para interpretar os comportamentos sociais. ${ }^{27}$

A validade do Direito consiste no conjunto abstrato e normativo de idéias que servem de molde interpretativo dós fenômenos do chamado Direito em ação. Destarte, são normas efetivamente obedecidas por serem socialmente obrigatórias. A concepção de Direito em ação deve ser pensada por meio de um conjunto de normas, após estar éstabelecida uma ligação com um conjunto de comportamentos sociais visualizados como um todo. Na seqüência, os atos sociais são identificados por meio da análise estrutural das ordens jurídicas nacionais. Tais ordens possuem duas formas: as regras de conduta e as regras de competência. As primeiras estabelecem o comportamento, já as segundas, dizem respeito à competência das autoridades. Consequentemente; as regras comportamentais só podem ser estabelecidas pelas autoridades instituídas pelas normas de competência (ambas constituem o ordenamento nacional). Cabe salientar sobre as regras de conduta que, para o autor, elas são diretivas aos Tribunais sobre o exercício de seu poder. Aos indivíduos; resta conhecer como o Tribunal julga determinado caso e, diante dessa informação, os indivíduos poderáo conformar suas condutas. Portanto, o Direito em açâo está contido no

\footnotetext{
A questäo da validade deve ser destacada pela diferente consideração que ela tem de Koss para os jusnaturalistas e para Kelsen. O termo validade, para Ross, indica existência de da norma ou do sistema de normas em contraposiçăo a regra pensada ou projeto de regra. A validade encontra-se completa se considerar a validade sendo a norma considerada pelo juiz como socialmente obrigatória; logo, a natureza da validade é psicológica, ao depender das consideraçôes mentais do juiz. Em suma, essas consideraçōes seröo pautadas pela ideologia juridica em vigor. BARZOTTO O Positivismo Juridico Contemporaneo. p. $71-74$ e 76.

${ }^{27}$ BARZOTTO, O Positioismo Juridico Contemporâneo. p. 68-70.
} 
conteúdo das sentenças dos Tribunais a vincularem, por meio da força física, aqueles resistentes a observar a sentença. Portanto, diante dessas noções e definições, é possivel encaixar o pensamento na corrente normativista. ${ }^{28}$

Em face dos conteúdos das sentenças dos Tribunais serem a expressão das regras jurídicas e, também, essas sentenças derivarem de um juiz dotado de convicção própria, o ordenamento jurídico só pode ser conhecido a partir de uma investigação dos sentimentos animadores das mentes dos juizes. Por meio dessa investigação o autor pretende encontrar a ideologia indicadora das normas válidas. Ele acredita num processo determinado de tomada de decisão sobre uma regra e não outra, que afasta a arbitrariedade, a formar uma ideologia comum presente entre os juízes. Essa ideologia possui a funçâo de indicar o caminho para o juiz desvendar as diretivas decisivas ao caso em debate. Logo, a ideologia não tem o condão de estabelecer a controvérsia jurídica, pois ela se mostra como um processo de reconhecimento do Direito, não ultrapassando o sentido tradicional de fonte jurídica. Ademais, a visualização da ideologia só pode ser efetuada por meio da observação da postura ética dos juízes. ${ }^{29}$

A esfera legislativa do Direito se refere às normas textuais como: a constituição, as leis emanadas do órgão legislativo, os decretos, os regulamentos etc. Tais normas recolhem sua autoridade diretamente das normas de competência, tendo a promulgação força legal. Elas, as normas, estabeleceram as condições formais e materiais do ordenamento jurídico, ou seja, determinam os procedimentos legislativos: quem está apto a legislar; o conteúdo das normas; como e quem deve criar outras normas de competência. Assim, o ordenamento vai se tornar mais complexo e adquirir uma forma hierárquica. A fórmula abstraída desse contexto se resume a ser a norma capaz de produzir norma de acordo com as condiçöes materiais e formais ditadas pela norma superior. A denominação

\footnotetext{
BARZOTTO, O Posituismo Jurídico Contemporáneo, p. $70-71$.

29. BARZOTTO, O Posituismo Jurídico Contemporâneo. p. 77-78.
} 
se restringe ao seguinte: norma "inferior" e norma "superior". A visão do ordenamento é exemplificada da seguinte forma: norma de competência 3 (nẩo produzida por nenhuma autoridade) institui autoridade 3; autoridade 3 produz norma de competência 2 que institui autoridade 2 ; autoridade 2 produz norma de competência 1 que estabelece autoridade $1 .^{30}$

Num esquema hierárquico, para não cair no infinito, é essencial formular uma norma básica que, segundo o autor, pode ser encontrada na Constituição formal Além disso ${ }_{*}$ é a norma depositária do poder de emenda à Constituição. Justamente ela é considerada norma superior às outras por ter a capacidade de elaborar normas constitucionais. Por conseguinte, têm-se dois níveis de normas constitucionais: o daquelas capazes de fazer ou emendar normas e o das normas elaboradas pelas autoridades instituídas pela norma suprema. A questão da norma básica instituidora dessa autoridade está numa "ideologia pressuposta", pois ela năo foi instituída por nenhuma autoridade. A partir de entắo, a hierarquia vai proporcionar a criaçäo de normas desde o topo até a base: a norma superior cria normas e autoridades que, por sua a vez, estabelecem normas e autoridades até chegar à base. Mas Ross possui uma particularidade nesse ponto. A autoridade máxima no sistema é a norma que possui o poder de reforma, logicamente por estar situada acima das demais normas constitucionais, embora materialmente seja uma norma constitucional. Em decorrência desse fator, o poder constituinte é instituído, assim a norma que instituí o poder não pode sofrer reforma, pois é autorreferencial e o pressuposto ideológico mais alto do ordenamento. A sua mudança é juridicamente inviável, mas sua alteração somente se dará por meio do fato psicossocial. ${ }^{3 t}$

Em relação à diferença entre a eficácia e a validade, a eficácia tem consistência na aplicação efetiva das normas pelos

3n BARZOTTO, O Positivismo Juŕdico Contemporâneo, p. $78-79$.

${ }^{3}$ BARZOTTO, O Positivismo Jurídico Contemporâneo. p. $79-81$. 
juízes ao passo que a validade encontra-se no elemento psicológico (no sentimento) dos magistrados. A validade é ligada à ideologia que, por sua vez, estabelece uma unidade das normas do ordenamento jurídico. Os juízes animam a validade das normas e a eficácia acaba por se tornar efeito da validade. Portanto, na prática as normas não aceitas/rejeitadas pelos Tribunais, como aquelas regras que se afastam da materialidade do ordenamento, perderão a validade por ineficácia. A adição da eficácía, na concepção de Ross, pode determinar a extinção da validade de uma norma ou estabelecer como válida uma prática criada pelos Tribunais. Entäo, aqui, a validade não se liga à ideologia, mas à eficácia ${ }^{32}$

\subsubsection{Hart}

Herbert Hart busca demonstrar a importância do conceito de regra na concepção do Direito e năo admite a redutibilidade do Direito à ordem coercitiva e ao hábito de obediência. Por issso as regras não podem ser fundamentadas em comandos ou ameaças, pois existem outras normas possuidoras de funções diversas dos comandos. Nomeadamente, há aquelas regras que criam condições de validade para algum ato jurídico, ao conferir poderes aos indivíduos a fim de regularem relações de caráter jurídico. Outro destaque está na esfera de aplicação da norma sob condições coercitivas, em que o comando, no Estado Moderno, está dirigido a uma classe ou generalidade de destinatários, inclusive ao(s) próprio(s) criador(es). Ainda a teoria da origem das regras legislativas não pode ser aplicada ao costurne, por faltar nesse a presença do elemento da vontade consciente em sua elaboração. Assim se dá com a insuficiência da idéia de hábito na exemplificação feita por Hart, quando da passagem da soberania de Rex para o Rex II. Logo, o autor demonstra a lacuna jurídica na sucessão de legisladores, pois as regras estabelecidas por Rex II só seriam consideradas jurídicas após a criaçăo do hábito de obedecer a ela.

32 BARZOTTO, O Positivismo Juridico Contemporânea. p. 82-83. 
De outro modo, se existisse uma norma estabelecendo o legítimo sucessor de Rex, portanto Rex II, as suas ordens adquiririam caráter jurídico no momento da posse do poder soberano. Portanto, a comparação entre a regra social e hábito ocorre das seguintes formas: para a existência de um hábito em um grupo basta uma convergência de comportamentos, e o desvio comportamental não resulta em reprovação. De modo inverso, na existência de uma regra social, a transgressão da regra implicará a reprovação por parte dos membros. A reprovação ao comportamento desviante é legítima, na existência da regrà social, por parte dos membros e até mesmo reconhecida pelos violadores. Tanto a regra social como o hábito possuem uma regularidade no comportamento capaz de ser observada (aspecto externo), mas as regras agregam uma atitude reflexiva em relação ao comportamento regrado (aspecto interno).$^{33}$

Junta-se, aqui, a concepção das regras que estabelecem a autoridade com a prerrogativa de legislar, portanto, de criar regra, com isso, elas explicam e legitimam a continuidade e as características da autoridade. Perante essa espécie de regra, identificam-se no tempo as pessoas aptas a legislarem. Porém, o autor invoca a observância de regras de legisladores passados, como do século XVIII, ao argumentar que não é por força de hábito a respectiva observação, mas justifica-se pelo emprego de referência atemporal por meio dos Tribunais e funcionários do sistema. Isso acaba por atribuir poder legislativo àqueles já mortos. Desse modo se constata, no fenômeno jurídico, a não-homogeneidade das regras, o que possibilitou, segundo a sua função, dividi-la em regras primárias e regras secundárias. As primárias têm como função estipular o dever, ao impor um comportamento a todos os cídadấos ou categorias de pessoas. Noutra função, estão as secundárias, elas estabelecem poderes e se referem a criação, a alteração e a aplicação das regras primánias. ${ }^{34}$

\footnotetext{
${ }^{33}$ BARZOTTO. O Positivismo Jurídico Contemparâneo. p. 97/100.

* BARZOTTO, O Positivismo Jurídico Contemporaneo. p. 100-102.
} 
As regras secundárias suprem a deficiência das regras primárias, por isso o esforço de Hart em destacar a necessidade delas nos sistemas jurídicos complexos. Por meio de um exercício de imaginação, o autor convoca argumentos para destacar a importância das regras secundárias. Logo, imagina-se um cenário de uma sociedade primitiva que possui, apenas, regras de caráter costumeiro aplicadas pelos próprios membros, poís nessa sociedade não existe o poder judiciário, nem o legislativo ou qualquer outro. Diante do cenário exposto, cabe arrolar os seguintes argumentos: a regra primária apresenta incertezas, por não delimitar quais as regras que podem ser consideradas regras da sociedade. Então, cabe recorrer à regra de reconhecimento, justamente para identificar quais são as regras a serem observadas pelo grupo.

O caráter estático das regras primárias apresenta-se como outra deficiência, pois o único modo de alterá-la é por meio da mudança de costumes. Nesse sentido, não existe como introduzir novos padrões de comportamento, porém, se existissem regras de alteração vinculadas ao poder legislativo, seria possivel inserir novos padrôes comportamentais. $O$ terceiro aspecto junge-se ao fato de a pressão social difusa causar ineficácia nas regras mantidas pela sociedade. A falta de regras indicadoras de como proceder à aplicação das regras primárias resulta em grande dispêndio de tempo do grupo em se auto-organizar para aplicar a regra e no crescimento da violência derivado da autotutela. Tais deficiências podem ser contornadas por regras instituidoras de um órgão julgador, a estabelecer se aconteceu a violação da regra e qual a sançăo a ser aplicada aos culpados. ${ }^{35}$

O sistema jurídico se estabelece com a junção de regras primárias com as secundárias e forma a idéía de sistema por meio da regra de reconhecimento ao aplicar a concepção de valídade. Como fundamento do sistema convoca-se, a situação social, em que todos os membros sociais instituem

35 BARZOTTO, O Posilivismo Jurídico Contemporầneo. p. 102. 
critérios (legislação, precedentes dos tribunais, costumes...) comuns a fim de identificar as regras instituidoras de obrigaçōes. A complexidade das sociedades atuais estimula a regra de reconhecimento a admitir vários critérios dispostos hierarquicamente até atingir o ponto supremo. $O$ critério supremo qualifica as regras reconhecidas por ele como regras do sistema. Entâo, quando as regras reconhecidas por outros crité rios colidem com as regras reconhecidas pelo critério supremo, aquelas deixam de ser regras do sistema.

A regra de reconhecimento raramente se encontra de forma expressa, sua existência é manifestada pelo uso dos tribunais e funcionários no momento de identificaçẫo das regras do sistema. Isso, segundo Hart, pode ser feito por meio da análise dos enunciados dos funcionários ou tribunaís que a empregam. Aqui são invocados dois fatores enunciadores da regra de reconhecimento: o ponto de vista intemo e o ponto de vista extemo. $O$ ponto de vista intemo revela a aceitação da regra; assim, o enunciado proferido por alguém reconhece a vinculação - ao expressar uma regra - da seguinte forma: "O direito dispôe que..." Em contraposição, do ponto de vista externo a regra não é aceita; no entanto, alguém observa a aplicação de um ângulo exterior - ao considerar o fato da existência de uma regra - por meio do seguinte enunciado: "No, Brasil, reconhecern como direito..." " Para Hart, a validade jurídica está imiscuída na diferenciação entre os pontos de vistas externo e interno. ${ }^{37}$

A validade da regra passa pela afirmaçăo intema, ou seja, está atrelada à identificação como regra do sistema ao se conformar aos critérios da regra de reconhecimento. A supremacia hierárquica da regra de reconhecimento é notória justamente por ser a última regra invocada ho processo de validação. Portanto, qualquer alteração, criação ou aplicação deve estar dentro dos parâmetros definidos por essa regra,

\footnotetext{
${ }^{36}$ Os exemplos dos pontos de vistaintemo externo sä̀ de: BARZOTTO, O Positivismo Junídico Contemporaneo. p. 104.

37 BARZOTTO, O Positivismo Jundico Contemporáneo. p. 103-104.
} 
pois está aí o termo de fundamentaçâo da validade de qualquer regra. Como a regra de reconhecimento fundamenta todo o sistema, ela não tem questionada sua (in)validade. Cabe acrescentar mais algumas consideraçöes dos pontos de vista interno e externo sobre a regra de reconhecimento. Internamente, ela é um padrâo identificador das demais regras do sistema por parte dos funcionários e juízes, por meio de referências às regras. Na perspectiva externa, ela constitui-se em fato, numa prática social complexa capaz de ser observada, tendo como referência os fatos ${ }^{38} \mathrm{~A}$ eficácia referida por Hart está em consonância com a obediência frequente e nẩo com a desobediência. Por isso, năo existe uma relaçâo necessária com a validade de uma regra concreta, porém, se a regra de reconhecimento incluir em seus critérios a regra do desuso, consequentemente vincula a validade à sua eficácia. ${ }^{39}$

Ao desenvolver esquematicamente o pensamento desses dois juristas, notam-se diferenças e semelhanças, embora o esforço, aqui, năo esteja localizado em distinções entre eles, mas em criar uma paisagem do positivismo propriamente jurídico. Säo dois autores (com certeza ficaram de fora inúmeros outros nomes) marcados por uma ratio especificamente moderna, pois se movimentam, cada qual com suas peculiaridades, na direção do cientificismo jurídico na busca cega pela segurança e certeza.

\section{Kelsen e Controvérsia}

A Reine Rechtslehre ocasionou e ocasiona no mundo jurídico um abalo. A lógica nela impregnada tornou-se um desafio analítico aos incursores do positivismo jurídico, em suas diversas formas, sem poderem ignorá-la por completo. Qualquer tentativa de estabelecer uma visão panorâmica nítida sobre as fundamentais correntes positivistas não pode

\footnotetext{
38 BARZOTTO, O Positivismo Juridico Contemporâneo. p. 104-105.

39 BARZOTTO, O Pósitivismo Juñdico Contemporâneo, p. 105-106.
} 
deixar de citar a Reine Rechtslehre, nem mesmo ignorá-la no estudo da norma e do ordenamento jurídico. Na realidade, o pensamento kelseniano marcou um espaço relevante no conhecimento jurídico. A firmeza da sua logicidade levoua - permanece ainda hoje - a inúmeras discussões sobre os componentes e sua teoria como um todo. Para visualizar o mundo positivista de Kelsen de outro ângulo não analíticoexpositivo de súa teoria, far-se-ão algumas inserçôes de interlocutores corn ele. ${ }^{40}$

\subsection{Kelsen versus Cossio em Cabral de Môncada ${ }^{41}$}

As circunstâncias a serem invocadas neste tópico dizem respeito ao encontro entre os dois juristas em Buenos Aires, em 1949. Ambos dialogam sobre a Reine Rechtslehre e a Teoria Egológica do Direito, a firm de esclarecer alguns pontos, já que o segundo pretende substituir a posição de teoria do Direito do normativismo kelseniano ao propor um condutivismo cossiano. O discurso de Kelsen foi intermediado pela posição socrática nos diálogos de Platão, assumida por Cóssıo. As questões destacadas circundam o objeto da ciência do Direito e os limites da Reine Rechtslehre em face à ciência. $O$ jurista austríaco distingue a ciência socionormativa das ciências naturais ao elencar dois aspectos da primeira: o estático e o dinâmico. O estático se refere puramente ao sistema de normas, sem relação com os atos de criação e aplicação do Direito. Está aí o objeto da ciência do Direito. O dinâmico considera a criação e a aplicaçăo do Direito, com isso, o seu objeto é constituído pela conduta humanà condicionada pelas normas. Embora exista essa distinçấo, a teoria kelseniana tem como objeto a norma. Foi convocada, tambérn, a distinçäo

\footnotetext{
40 Esses interlocutores e as respectivas fontes bibliogräficas sâo aquelas disponiveis no momento. Não se ignora a existência de numeros outros interlocutores e fontes mais qualificadas e diretas.

4) Esse tópico é inteiramente baseado numa recensăo do livro Kelsen-Cossio: Problemas Escogidos de la Teoría Pura del Derecho em MONCADA, Luís Cabral de. Estudos de Filosofia do Direto e do Estado. v. II. Lisboa: Imprensa Nacional Casa da Moeda, 2004 p. 319-324.
} 
entre Rechtsnorm e Rechtssatz. Mas o jurista austríaco não se limita à análise da lógica estrutural das proposiçōes nem ao exame lógico da regra de Direito. Está clara a necessidade do emprego da lógica na análise do dever ser, não podendo ela, isoladamente, constituir a teoria do Direito. Encontra-se, conjuntamente, a especificação do conteúdo das regras de Direito em contraponto às demais regras sociais; só a teoria geral do Direito está apta para delinear as concepçôes jurídicas e os preceitos fundamentais como sançăo, obrigação, responsabilidade [... . ${ }^{42}$

Em face do exposto, a reação de Cossio foi reconhecer a aproximaçẫo do pensamento da teoria pura com o egológico no condizente ao chamado axioma ontológico (tudo o que não está proibido, está permitido) e da característica lógico-formal do nexo imputativo do Sollen. No entanto, o problema ontológico da conduta a despontar como objeto único da ciência do Direito, fundamento da teoria egológica, causa a divergência básica entre os juristas. A divergência concentra-se na incidência do sentido normativo na conduta humana. Para o condutivismo cossiano, a conduta constitui as normas jurídicas, que são esquemas interpretativos da conduta; logo, o jurídico existe ontologicamente antes das normas. Para o normativismo kelseniano, as normas constituem as condutas como jurídicas, a existência antecipada da norma jurídica transforma a simples conduta em juridicamente relevante. As diferenças entre os dois juristas năo se resumem a essas nem aos idiomas, por tanto, a aproximação entre as duas concepçôes é impossível em face às inconciliáveis Weltanschaưung. A base de pensamento de Kelsen está calcada no neokantismo de Marburg que reconhece unicamente a existência lógica do Sollen; tal idéia afasta questōes ontológicas do Direito, ao colocámas como sem sentidos ou como falsos problemas. ${ }^{43}$

Cossio entende o Direito de outra forma: fundamentalmente, ele é existencialista, fenomenólogo e engajado culturalmente. Por essas qualificaçōes, pode-se visualizar um abismo

\footnotetext{
42 MONCADA, Estudos de Filosofia do Direito e do Estado. v. II. p. 320-321.

43 MONCADA, Estudos de Filosofia do Direito e do Estado v. il p. $322-323$.
} 
intransponível entre os dois juristas e as duas teorias. $\mathrm{O}$ argentino carrega ontologicamente sua concepção com a existência e a cultura na mesma direção. Aposta numa teoria dos objetos na qual introduz a idéia de objetos culturais como reais e capazes de serem experimentados. Ademais, sua postura existencialista e heideggeriana atribui a liberdade à essência do ser humano. Por conseguinte, o Direito se reveste de condutas produzidas por seres livres. No kelsenianismo, a existência e a liberdade não possuem sentido no Direito. A liberdade, entáo, é assumida como marco final da imputaçãó normativa, sendo que a existência nâo ultrapassa a categoria de símbolo. Os mundos criados pelas duas teorias se encontram, somente, na lógica jurídica; nos demais pontos são opostos e distintos, sendo impossivel o advento de uma superação teórica de uma teoria em relação à outra. Nắo existem pontes possíveis de serem construídas entre elas, inclusive uma dialética seria inconcebível, por se tratar de linguagens distintas. Portanto, o diálogo foi marcado mais pela simbologia diplomática do que pela científica. ${ }^{44}$

3.2 Castanheira Neves: seu diálogo com Kelsen ${ }^{45}$

O diálogo travado por Castanheira Neves com a concepção kelseniana coloca na perspectiva da unidade sistemática o ponto central da discussão. A hipervalorização do teorético em face da práxis estrutura o cunho científico da sistemática do Direito; uma reflexão intensamente elaborada pelo jurista austríaco a ponto de transformá-la no principal problema epistemológico do século XX A separaçáo metodológica da ciência do Direito das demais esferas do conhecimento, principalmente, da sociologia e da política foi fruto da orientação do dualismo neokantiano. A intenção de empregar esse mecanismo fundamenta-se no desejo de estabelecer

\footnotetext{
4. MONCADA, Estudos de Filosofia do Direito e do Estado. v. Il. p. 323-324.

${ }^{45}$ Tópico baseado em. NEVES, António Castanheira. A uniddde do sistema juridico: o seu problema e o seu sentido (diálogo com Kelsen). In. Digesta. Escritos acerca do Direito, do Pensamento Jurídico, da sua Metodologia e Outros. V. 2. Coimbra: Coimbra Editora, 1995. p. 95-180.
} 
a pureza do objeto e da teoria. O jusfilósofo de Coimbra também intenciona manter a autonomia do Direito em relação à sociologia e à política, porém insiste na autônoma problematização do fato em termos axiológico-normativo. Nesse sentido, não se abandona o fato, simplesmente recupera-se, em face do Direito, o controle da regulação normativa de validade axio-lógica. Em face à política, também nầo se deve impingir à esfera jurídica a completa absorção das vontades originadas na política sem, ao menos, considerar o pensamento jurídico da legitimidade. Embora se mantenha a autonomia do Direito, é preciso estabelecer uma dialética com a sociologia e com a política, a fim de não ingressar num ideal abstrato nem perder o fundamento de validade normativa do político ${ }^{46}$

É necessário compreender a intenção do jurista português em refutar a pureza do método e do objeto, pois o Direito é lançado na prática da vida com uma intenção de validade axiológico-normativa a enfrentar a problemática histórica. Para tal, o pensamento jurídico é convocado a assumir essa problemática com a intenção de dever ser. Por conseguinte, ele não observa diferença entre a intenção do Direito e a intenção do pensamento jurídico. Este deve assimilar a primeira intenção e realizá-la na prática. Tal pensamento diferencia-se do kelseniano pela tomada prática de posiçầo, distinguindo-se da indiferença ao sentido axiológico-normativo do Direito com o objetivo de construir um conhecimento formal sobre ele. Traduzindo de forma direta: o pensamento jurídico não deve servir à ideia de ciência, mas à ideia de Direito. A cisão entre os dois juristas concentra-se, nesse momento, no objetivo que cumpre o pensamento jurídico frente à realidade da vida. Se o austríaco pretendia estabelecer um conhecimento alheio a qualquer influência externa, o português visa manter a autonomia do Direito sem, no entanto, perder de vista a realidade problemática da vida. Portanto,

\footnotetext{
«s NEVES, A unidade do sistema juridico. p. 95-103.
} 
o problema de Direito não é epistemológico, mas sim, práticonormativo. ${ }^{47}$

É primacial compreender a diferença da questấo da unidade do sistema jurídico diante do jurista português. Para ele, a unidade concentra-se no sentido prático-normativo do Direito e não em um sistema teorético da ciência jurídica. Aqui existe o distanciamento conceitual da Wiener Schule de um postulado do conhecimento jurídico, mas como ordem prática, não tanto como unidade objetiva, mas como unidade intencional. A unidade não é algo dado previamente nem descoberto pela interpretação, ela resulta do movimento prático-normativo. Assim, a unidade não se cumpre na abstração do princípio da igualdade generalizado de modo formal; ela exige a interferência no nível das circunstâncias concretas da sociedade, ou seja, da igualdade material. Isso corrobora a descrença na dedução sistemático-conceitual e afirmativa da realização normativo-constitutiva na aplicaçăo do Direito.

Desse conjunto de esclarecimentos decorrem, correlativamente, então, a justiça no sentido material e a historicidade, o que revela uma intenção "aberta" do sistema. Tal abertura indica a insuficiência da unidade abstrata do sistema, mas não significa que os casos jurídicos se limitem àqueles abstratamente previstos nem que os critérios normativos para a realização do Direito sejam exaustivos. Se o Direito não está limitado pela unidade abstrata pré-estabelecida, a segurança jurídica se estrutura pela noção de continuidade ao considerar a concreta e mutável realidade social, a fim de responder validamente à adequação exigida. Por conseguinte, a estabilidade se sustenta na continuidade e essa, na unidade; portanto, a importância da unidade não é apenas teorética, mas prática ${ }^{48}$

O desacordo com Kelsen em relação à unidade do sis. tema está na perspectiva de considerá-la como problema

\footnotetext{
a7 NEVES, A unidade do sistema juridico. p. 103-109.

NEVES, A unidade do sistema juridico. p. 109-111 e 120-124.
} 
posto no momento da realização do Direito, ou seja, ao enfocá-la dessa forma, a pressuposição existencial abstrata do sistema é posta em causa. Logo, o esclarecimento do problema, para o autor português, encontra-se na metodológica fenomenologia da realização do Direito. A partir de então dar-se-á o ponto de corte nas respectivas teorias no referente à unidade. Se o pensamento kelseniano não ultrapassa a fronteira estrutural-formalista, Castanheira Neves avança no sentido da prática normativa para a constituiçăo da unidade jurídica e do Direito. Este não foge à dimensão histórica e isso implica não se restringir ao desenvolvimento intra-sistemático, pelo contrắrio; o transcende. Alếm disso, o sentido normativo constituendo constituído não se resume a um único momento ou patamar do pensamento jurídico. ${ }^{49}$

A normatividade jurídica não está destituída da dimensão axiológica como pretendia Kelsen, ao desvencilhar o axiológico do jurídico - pelo menos em sua análise científica do Direito - pois, para o jurista português, ela é o fundamento da normatividade. Logo, aqui existe o afastamento do dogma empírico-analítico que assume grande relevância no pensamento kelseniano. A distinção relevante não está plasmada unicamente no afastamento dogmático, ela se encontra no axiológico. $\mathrm{O}$ elemento axiológico estabelece os pressupostos sentidos de validade objetivados como todas as realizações do considerado humanamente significante. Portanto, o crucial focaliza se no momento axiológico para delinear a essência da normatividade, ou seja, isso provoca a necessidade de reconhecer, na dimensão valorativa, o fundamento de normatividade e, ao mesmo tempo, contraria a dimensão finalista. A constituição desse momento axiólógico provoca a autonomia da instância de validade, mecanismo capacitado a manter a autonomia do Direito em face da política.

\footnotetext{
NEVES, $A$ unidade do sistema jurídico. p. 124 e 132. Em face de o trabalho estar restrito ao pensamento kelseniario, nåo se aprofundara a visăo do jusfilosofo português. Para a compreensão dessa metodológica fenomenologia, vide p. 124134 .
} 
Nesse ponto constitutivo da própria dimensão jurídica, o austríaco se limitou a imaginar a formalidade da Grundnorm, diferentemente da dimensão jurídico-material decorrente da axiologia. ${ }^{50}$

O fator dogmático do Direito possibilita a objetivação racionalizada e sistematizada do nómativo, o que significa admitir a correlação entre a matéria e a forma. Os princípios fundamentais da senda normativo-jurídica precipitam a validade axiológica dogmatizada. Esta dogmática não é confundível com a teológica a ontologizar a normatividade absoluta de um sistema fechado. Pelo contrário, a dogmática abordada demonstra duas características principais: abertura sistemática e problemática dialética, ou seja, na sua formação e realização. Com isso, a dinâmica do sistema jurídico atua constitutivamente sem plasmar-se em pontos fixos da História nem em conceitos estáticos; ou seja, não se toma vulnerável às influências externas e, com isso, mantém sua autonomia. A abertura somada à dialética estrutura o sistema para enfrentar, coerentemente, as mudanças sociopolítico-econômicas, sem expor o Direito ao simples formalismo fechado. Ainda, as tais características são capazes de adaptar o sisterna à intersubjetividade, que derrubou o modelo ideal do sistemático a priori. ${ }^{51}$

O pensamento kelseniano concebe uma unidade normativo-sistemática de unidade lógica a priori. Tal unidade de relacional conexão não é uma abstrata unidade lógicoconceitual, é uma unidade capacitada a institucionalizar um processo normativo e dinâmico, a fim de produzir (aplicar) o Direito, tendo como fundamento legitimante-normativo a Grundnorm. A partir daí, a unidade sistemática é desenvolvida pelo escalonamento de competências normativas, legitimado a criar normas hierarquicamente inferiores de intenção concretizadora. Embora a atribuição dinâmica do sistema jurídico kelseniano seja verificada nas normas inferiores,

\footnotetext{
50 NEVES, A unidade do sistema juridico. p. 134-140.

53 NEVES, A unidade do sistema jurídico. p. 144 147.
} 
a Grundnorm não apresenta tal qualificação, seu caráter estático não abre espaços para a dialética própria do normativo jurídico nem admite outro sentido do movimento dialético, o de baixo para cima. Esse problema é oriundo do próprio esquema intelectual do racionalismo teorético-sistemático-analítico pois, no caso kelseniano, somente é pensada a normatividade e abandonado o elemento condicionante do histórico-concreto jurídico, o que, para o jurista português, afạsta a autêntica realização do Direito. ${ }^{52}$

A pressuposição da Grundnorm provoca a pressuposiçâo das demais nórmas sem verificação, constituindo-se no sentido normativamente dogmático. Desse modo, deixa-se a validade normativa para a assunção da validade lógica. As consequências disso estão na juridicionalização da estrutura do sistema coativo de normas do poder. Os limites de atuação do poder não se encontram na idéia de "justiça", somente na lógica implementada pelo sistema normativo. O fator material, nesse caso, não compõe a dimensão jurídica a ser concretizada, ele se mantém na senda do pensamento e é atribuído às outras áreas da cultura. Por conseguinte, a normativa unidade prática jurídica também é relegada. ${ }^{53} \mathrm{~A}$ questão a ser ressaltada é a insuficiência da lógica dos pressupostos na missáo de concretizar o Direito. Os referidos pressupostos não alcançam as exigências problemáticas impostas pela dinâmica social. A crítica portuguesa acentua o vazio material como uma insuficiência de essência normativa do Direito, a qual impossibilita a construção de uma resposta adequada ( $a$ posteriori) ao problema a ser respondido pelo Direito. Porém, isso năo implica o completo fechamento do sistema, pelo contrário, é importante a aberturá sistemática com a reconstrução dialética numa frequente constituenda ordem de alteração. ${ }^{54}$

\footnotetext{
NEVES, A unidade do sistema jurídico. p. 155-159.

53 NEVES, $A$ unidade do sistema jurídico. p. 160-161.

5 NEVES, A unidade do sistena juridico. p. 171.
} 
A divergência entre os dois jusfilósofos concentra-se no desinteresse kelseniano pelo aspecto normativo material e pela plena preocupação com a formal analítica da idéia de pureza científica do Direito: a ingenuidade de considerar a ciência pura algo afastado da dominação do poder. Essa concepção deixou de ser verificável no momento do emprego de sua teoria para justificar atos de autoritarismos. Mas o jurista austríaco exilado não intencionava entregar o Direito nas mãos dos déspotas, apenas queria resguardá-lo deles. Em suma, a divergência latente entre os dois juristas está na consideraçäo formal e material do Direito ${ }^{55}$

\subsection{Kelsen em Ortega y Gasset ${ }^{56}$}

Os dois autores, em suas trajetórias de vida, náo chegaram a se encontrar, mas entraram em contato com uma filosofia em comum durante os respectivos períodos de aprendizagem: a neokantiana da Marburg Schule. Outras duas semelhanças estão: a) nos díscípulos em comum - Luis Recanséns Siches e Luis Legaz Lacambra (indiretamente); b) na circunstância de viverem em exilio. Mas, os dois tiveram sortes distintas nesse período: Kelsen seguiu sua carreira acadêmica nos Estados Unidos da América, ao passo que Ortega y Gasset perambulou por diversos locais, até retornar à Espanha, em 1945, para readquirir o status de repatriado. Destaca-se a falta de evidências de um encontro entre os dois pensadores, mesmo quando o último esteve nos Estados Unidos da América. Porêm, isso năo infere o desconhecimento recíproco das respectivas concepçōes teóricas, pois o filósofo espanhol, em toda a sua obra, cita duas vezes o austríaco. Além do mais, os dois discípulos foram, de forma determinante, influenciados pela doutrina kelseniana a ponto de publicarem estudos direcionados a analisar a teoria pura. Já o austríaco,

\footnotetext{
5 NEVES, A unidade do sisterna jurídico. p. 180.

* Tópico baseado em: LLANO ALONSO, Femando H. Las glosas de José Ortega y Gasset a Hans Kelsen. In: Rivista Internazionale di Filosofia del Diritto. S. V, anno LXXXII, n. 3 - luglio/settembre. Milano: Giufre, 2006, p. 407-434.
} 
ao longo de sua obra, não menciona o madrileño; no entanto, devido aos discípulos em comum, ao interesse em temas comuns e à grande divulgação - em diversos idiomas - do livro La rebelión de las masas (1930), pode-se inferir o possível conhecimento da concepção, mesmo resumida, do pensamento orteguiano. 57

O primeiro aspecto a ser invocado se refere à crítica de Ortega y Gasset ao hermetismo da Reine Rechtslehre ao escrever sobre o pintor Diego Velázquez e a evolução estética e técnica da pintura no decorrer da História. Ao analisar essa evolução, o filósofo espanhol reconhece a mudança em todas as esferas da cultura humana. Em relação ao nexo entre 0 pintor e o jurista, ele estabelece o hermetismo cerrado a distinguir, radicalmente, o conhecimento técnico do profano. Isso significa compor uma política para os políticos, um direito para os juristas [...]. Essa perspectiva é marcada pelo tempo vivenciado pelo madrileño em uma época propensa ao domínio da especializaçâo do conhecimento científico que ele considera bárbaro, típico do homem-massa. A tentativa de buscar a pureza metodológica, do Direito, eliminando todos os elementos considerados estranhos do campo de visão jurídico, faz Kelsen constituir, para o espanhol, um jurista-bárbaro. Destaca-se, novamente, que os discípulos orteguianos foram influenciados pela doutrina kelseniana assim como inúmeros juristas do século $\mathrm{XX}$.

Todavia, Ortega não se entusiasma com a autossuficiência e a assepsia das ciências, o formalismo do positivismo jurídico, o resplandecer do arbítrio do poderoso (dominador) ou com $o$ aporte da ideia de neutralidade, em que julga ter esquecído a essência do Direito. Ele segue a crítica dos jusfilósofos do Nachkrieg, no sentido de Radbruch, excetuando a aproximaçăo com o conceito de jusnaturalista. $\mathrm{O}$ filósofo está mais próximo do formalismo ético adotado pelo Bobbio, rechaçando qualquer critério de justiça além do Direito positivo, ou seja,

57 LLANO ALONSO, Las glosas de José Ottega y Gasset a Hans Kelsen. p. 407-41\%. 
da lei ${ }^{58}$ Nesse ponto, ele se aproxima de Kelsen, porém se afasta na forma de conceber a ciência jurídica como análise focada na norma jurídica embasada em juízo lógico-hipotético conectado à medida coativa. Para o madrileño, a modificaçăo do Direito é um fato social, uma realidade encontrada nas relaçoes interindividuais da vida coletiva, um fato que demonstra um comportamento exemplar para a manutenção da própria coletividade. Por ele se fundar em toda a vida de uma comunidade. $O$ filósofo nâo admite o ato coativo do Estado como sustentáculo do Direito nem que exista uma identificação entre ambos. ${ }^{59}$

Outro ponto de crítica orteguiana se encontra no positivismo e nomativismo kelseniano. $\mathrm{O}$ ataque é desferido contra o fundamento de o Direito estar calcado unicamente em algo juńdico Assim, o Direito não pode estar fundamentado só em algo jurídico nem mesmo a ciência tem seu último fundamento em algo científico. Em face de tal crítica, cabe situar o filósofo na neokantiana Marburg Schule. Ortega distancia-se do formalismo idealista de tal Schule, ao tentar preencher os conceitos kantianos vazios do bom e do justo, mas reconhece que sua educaçăo baseou-se no neokantismo. Segundo ele, para aprender filosofia, seria necessárió estudar na Alemanha, porque, na época, a filosofia de Marburg era o ponto de referência de inúmeras universidades alemăs. Por isso, não poderia esquivar-se de penetrar, até as últimas consequências, no sistema filosófico neokantiano. Sua intenção era compreender profundamente tal teoria para buscar uma saída/alternativa, porém ele nāo recusa a sua origem teórica, apenas tenta evitar cair na ontofobia - reducionista dos objetos da experiência em conteúdos da consciência de seus mestres de Marburg. Seu ponto de discordância está na admissão bidimensional do Homem; para o madrileño, existem as dimensóes objetiva e subjetiva, ou seja, uma parte

s LIANO ALONSO, Las glosas de José Ortega y Gasset a Hans Kelsen p. 412 -417.

59 LIANO ALONSO, Las glosas de Josê Ortega y Gasset a Hans Kelsen p. 417-420. 
vital e outra racional, inseparáveis do ser. Assim, o conceito de Direito encontra-se na realidade social, ao contrário da tese do normativismo formalista, de Kelsen que não escapa da responsabilizaçăo inerente às consequências do neokantismo ${ }^{60}$

A partir do desvio conceitual orteguiano, o Direito assume uma perspectiva raciovitalista. Para o filósofo espanhol a sociedade constitui um sistema de vigéncia social, significando um conjunto de usos que exercem sobre cada indivíduo uma coação, portanto, um sistema normativo. Nota-se que esses usos não são meros fatos sociais ou simples con dutas repetidas, pois eles reúnem algumas características particulares; a) coatividade, b) irracionalidade, c) processo lento de formação; d) normatividade; e) vigência social. Nesse talante, existe a divisão em usos débeis e difusos, aqueles correspondentes aos usos e costumes, os tratos sociais e usos fortes e rígidos, participantes do Estado de Direito (a economia, a política, o direito). Essa distinçẫo baseia-se no grau de obrigatoriedade. O Direito, portanto, para ele, é uma classe ou um conjunto de usos diferenciados - por suas características - de outras classes de usos.

Embora exista normatividade nos usos orteguianos, sua diferença da idela kelseniana focaliza-se na concepção jurí dico-formalista dessa última em face da jurídico-sociológica do madrileño. A vigência possui função análoga à validez do sistema kelseniano, sendo a norma um Sollen independente de sua eficácia, e sua validade atrela se ao essencial idealizado. A concepção orteguiana vincula a validade à sua eficácia; já a coação näo é realizada pelo Estado (Kelsen), mas pela opiniâo reinante, capacitada a coagir os indivíduos a agirem conforme os usos sociais e a impedir a produção de comportamentos antissociais. Logo, a figura do Estado não tem o sentido de coator dos indivíduos. ${ }^{61}$ Em suma, o ponto nodal localiza-se entre o Sollen e o Sein na perspectiva de

\footnotetext{
thaNO ALONSO, Las glosas de José Ontega y Gasset a Hons Kelsen. F. 421425.
}

- LLANO ALONSO Las glosas de José Ortega y Gasset a Hans Kelsen. p. 427-431. 
enquadramento do Direito. Se para Kelsen o Direito se manifestava por um Sollen, para Ortega y Gasset o Sein compunha o Direito com traços de Sollen, embora prevalecesse o Sein.

\subsection{De Kelsen para Ross ${ }^{62}$}

Primeiramente, destaca-se que Ross foi aluno de Kelsen e, em muitos pontos, seguiu caminho oposto ao de seu professor. A sua respeitável fama de expoente da escola Realista do Direito evidencia o seu afastamento de concepçóes do jusfilósofo austríaco, porém esse escreve algumas consideraçöes/observaçôes sobre On Law and Justice ${ }^{63}$ De iní cio, Kelsen chama a atenção para a diferença do trabalho de Ross(Towards a Realistic Jurisprudence) em relaçăo à sua Reine Rechtslehre. Ross, este defende uma teoria realística que a compreende o caráter empírico de negação da especulaçấo metafísica e de tendência de Seinstatsachen. Ressalta Ross que a noção legal deve ser interpretada como concepção da realidade social. Porém, a Reine Rechtslehre nấo se aproxima do conhecimento empírico do Direito, pois seu objeto é a norma ou o sistema de normas, sendo a norma a prescriçäo do Sollen e não um Seinstatsache. Assim, o conhecimento pode ser dirigido ao Seinsakt ou ao Soll-Sinn. No entanto, entre os dois objetos existe a diferença de o primeiro ser real e do segundo ser um objeto ideal A questão concerne à distinção existente entre as duas dimensóes: a do fato e a ideal, ou seja, como se conduz o Homem e não como ele deve conduzir-se; entẩo Ross aproxima o conceito de Direito ao conceito de realidade social. 64

austríaco destaca algumas passagens no On Law and Justice referentes à ciência do Direito e ao Direito, sendo que

\footnotetext{
${ }^{62}$ Tópico com base em: KELSEN, Hans. Eine "Realistische" und die Reine Rechislehre. Bemerkungen zu Alf Ross: On Law and Justice. In: Österraichshe Zeitschrift für offentliches Recht. Band X. Wien: Springer, 1959/1960. pp. 125.

3 BOBEIO. Norberto. O positivismo jurídico. Liçóes de filosofia do Direito. Trad Márcio Pugliesi, Edson Bini, Carlos E. Rodrigues. São Paulo: Ícone, 1995. p. 157.

"KELSEN, Eine "Realistische" und die Reine Rechtslehre. p. 1-2.
} 
ele diferencia o Direito como um complexo de regras e a ciência do Direito como o conhecimento das proposiçōes jurídicas. Isso implica o reconhecimento do Direito como norma prescritiva e o Direito como ciência descritiva. Ainda ressalta que as normas (advindas das leis contidas nos estatutos ou das normas oriundas dos precedentes) do Direito prescrevem determinada conduta. Logo, essa forma, a diretiva para a decisão jurídica, considera, ainda, o sistema nacional como um corpo integrado de regras disciplinadoras da coerção estatal. A teoria realista encontra-se, nesse sentido, em consonância com a Reine Rechtslehre, ao considerar o Direito um sistema de coação de normas ordenadas orientadoras de certos órgãos jurídicos, as quais, em determinadas condições, serão impostas (normas coativas) contra os indivíduos. Kelsen, em face disso, afasta o Sein como objeto da realistischen Rechtswissenschaft e aproxima o Sollen. Ademais, no escrito Towards a Realistic Jurisprudence, o Direito é concebido como Seinstatsache, no momento em que ele busca separar o ponto de vista normativo do conceito jurídico e determiná-lo como puro fato. 65

Ao estabelecer a forma do objeto do Direito e da Ciência do Direito, Ross cria uma contradição, segundo o jurista austríaco; por conseguinte, não é possível conceber o Direito como norma, no sentido de dever prescritivo e, ao mesmo tempo, qualificar a Ciência do Direito como uma descrição do Seinstatsache (no sentido de ciência empírico-realista). $\mathrm{O}$ aspecto empírico da Ciência do Direito permanece na descrição da norma estabelecida, sem tangenciar o Sollen: o Sollen da Rechtsnorm possui o sentido de prescrição imperativa, já o Sollen do Rechtssatzes se expressa no sentido da descrição indicativa. Segundo Kelsen, a Jurisprudez tradicional confunde Rechtsnorm e Rechtssatz e não distingue claramente o Direito da Ciência do Direito, mas Ross evita esse erro. Este jurista classifica as Rechtsnormen como directives,

\footnotetext{
${ }^{65}$ KELSEN, Eine "Realistische" und die Reine Rechtslehre. p. 3-4.
} 
já as proposições (Sätze) da Rechtswissenchaft sé manifestam nas doutrinas, nos livros de Direito. Porém, um ponto destoante da Reine Rechtslehre está na negação de a Rechtsnorm ser uma proposição descritiva da Sollsätze, assim, a proposição (Satz) ê um Seinssatz, ou seja, uma afirmação sobre o Seinstatsache. Ross nâo percebe que a palavra Sollen possui, além do caráter de prescrição, o caráter de descrição, com isso, pode-se inferir - na toada de Kelsen - a existência de diferença no emprego de Sollen na Rechtssatz e na Rechtsnorm: na primeira, a palavra se apresenta como um juízo lógico, ao passo que, na segunda, pode constituir-se na realidade (verdade) ou nâo-realidade (não-verdade) ${ }^{6}$

Outro ponto de afastamento entre as duas teorias (a Reine Rechtslehre e a realistische Rechtstheorie) encontra-se num problema importante e difícil para as Teorias positivas do Direito: as relaçôés entre o Sollen do Direito e o Sein da realidade natural. Assim, são necessárias algumas consideraçōes entre esses dois polos. Há de se considerar o Direito positivo como as Soll-Normen estabelecidas por melo de um ato humano que são consideradas, também, em sua grande e total eficácia. Com isso, a Teoria positiva do Direito encontra-se no meio de duas teses polarizadoras. Num polo localiza-se a tese de que entre a Geltung, como um Sollen, e a Wirksamkeit, como um Sein, năo existe relação alguma, sendo as duas totalmente independentes uma da outra. No polo oposto estão aqueles que creem na total identidade entre a Geltung e a Wirksamkeit. Os dois polos apresentados mostram traços falsos, pois o Direito não se restringe ao plano ideal nem somente ao plano concreto (dos fatos), isto é, a norma jurídica prescreve dentro de determinadas condiçốes de que maneịra o Homem deve

\footnotetext{
KELSEN, Eine "Realistische" und die Reine Rechtslehre. p. 48; para demonstrar sua tazăo, o austriaco utiliza o exemplo dado pelo prapiro Rass da lei penal da Califómia. Segundo Kèsen, em suma, a Satz não é uma descriçá, por isso, se o policial prender ou não o criminoso, ela continuará possuindo sua validade, significa dizer, a Satz gostaria que a prisão do criminoso se realizasse, todavia, se isso năo ocorrer ela continuará com a plena validade. Por ísso, ela nấo pode ser descritiva, sob pena de näo ser verificada ou não corresponder à realidade com a proposição. (p. 7 ).
} 
proceder; caso ele não proceda da maneira determinada existe a prescrição de um ato sancionatório a ser aplicado, pelos órgáos jurídicos, ao faltoso. Encontra-se aí a junçăo ao ideal (Sollen) e do real (Sein) no momento em que a prescrição de um dever torna-se um fato. No entanto, ressalta Kelsen, a Soll-Norm permanece com sua Geltung, quando esta não atinge a plenitude de sua eficácia (toma-se fato); diante disto, a Geltung não se identifica com sua Wirksamkeit. Portanto, em sentido oposto a esse, Ross baseia-se na identificaçāo da Geltung com a Wirksamkeit.67

Segundo Kelsen, em Towards a Realistic Jurisprudence, Ross identifica o dualismo da Reine Rechtslehre como um erro fundamental. A "validity" nảo é nada mais do que experiências subjetivas de impulsos/motivos dirigidos à ação. Assim, no conceito objetivo de Soll-Geltung será racionalizado esse impulso/motivo em direção a uma determinada conduta, porém ele a considera um erro, pois a racionalização provém da impossibilidade da teoria do conhecimento realizar tal operação, deixando a sem sentido. Logo, significa o abandono do conceito de validade normativa do Direito referente àquilo que não seja Seins-Wirklichkeit, sob pena de tornar a Geltung somente uma palavra. Este autor acredita poder dar outro significado à Geltung do que aquele constante na Reine Rechtslehre. Então, a Geltung não é Soll-Geltung, mas um Tatsache - um impulso (behaviour attitude) a determinada conduta sob o respeito à autoridade ou o medo do exercício da coaçăo prescrita na norma jurídica. Destarte, a própria validity se insere no âmbito da reality, já como um fato real Ele elimina o conceito de Geltung como idéia normativa, mas devido ao objeto da Rechtswissenschaft ser uma conduta humana, um Seinstatsache, a Geltung nâo pode ser seu critério de idela normativa. Em face disso, Kelsen destaca que näo cabe indagar se o fato vale ou não, mas se ele existe ou năo; somente a Soll-Norm pode ser questionada se vale ou não. ${ }^{68}$

\footnotetext{
67 KELSEN, Eine "Realistische" und die Reine Rechtslehre, p. 9-11.

68 KELSEN, Eine "Realistische" und die Reine Rechtslehre. p. 11 15.
} 
Cabe ainda destacar a observação kelseniana da Geltung na teoria Rosseniana: portanto, dado que a Geltung é um motivo determinado em cada conduta fática, isso a indica como a Wirksamkeit do Direito, que não se reduz a simples aplicação por um órgão jurídico ou o medo da sanção. Ela é também um cumprimento fático por meio da sujeição do indivíduo pelo Direito. $O$ conceito de Geltung apresenta dois fatores: um é externo, o físico; outro é interno, o psíquico. A Wirksamkeit do Direito corresponde à conduta jurídica é um determinado motivo para ela. Todavia, Kelsen insiste em destacar a diferença de Geltung e Wirksamkeit principalmente no que diz respeito à precedência da Geltung sobre a Wirksamkeit, no sentido de que, antes de qualquer juiz aplicar a norma ao caso, ela já possui Geltung. Também pode ocorrer uma conduta que deveria ser sancionada conforme a norma jurídica, porém acabou por não ter sido aplicada a sanção ao indivíduo, mas nem por isso ela perde sua Geltung. Encontra-se, nestes exemplos; a impropriedade da negação, por parte de Ross, do dualismo entre Sollen e Sein, que ele acreditava ser uma separação metafísica, já que é a imanente validade do positivismo jurídico. As críticas de Ross são em direção ao caráter formal da validade da Reine Rechtslehre. ${ }^{69}$

Na mesma negação do dualismo, Ross ataca a Grundnorm, porém Kelsen defende-se na mesma linha acima exposta. Portanto, em último momento, cabe destacar que a Positivität do Direito não é a sua validade, mas é a norma cujo ato humano a estabelece. ${ }^{70}$

\section{Conclusão}

O positivismo jurídico kelseniano é objeto de inúmeras análises teóricas e práticas e ainda serve de paradigmas aos diversos juristas no momento de pensarem as instituiçóes juridicas e o Direito em si mesmo depois dos reflexos pós-guerra.

\footnotetext{
69 KELSEN, Eine "Realistische" und die Reine Rechislehre. P. 16-22.

70 KELSEN, Eine "Realistische" und die Reine Rechislehre. p. 23"25
} 
Por isso, não é de um todo retrógrado analisar esse positivismo, mas ao mesmo tempo, nấo traz nada de inovador às atuais discussōes sobre o Direito. Ao reconhecer essas duas perspectivas, o desenvolvimento da abordagem desse positivismo atravessa alguns elementos peculiares do pensamento do austríaco, por vezes encobertos por outros ângulos de visão. O encobrimento é justificado pela impossibilidade, em pesquisas gerais, de observar os detalhes contidos nas obras e no pensamento de Kelsen, Embora ele tenha sido cuidadoso na forma de sistematizar seu pensamento e expor sua teoria, o entendimento torna-se complicado quando se parte de précompreensão diferente e em épocas distintas. Outra questão importante nos primeiros momentos da análise é, justamente, a multiplicidade de visões sobre o positivismo como movimento da cultura em geral. Conforme a aplicação de uma das diversas teorias positivistas, o Direito muda por completo a visão jurídica, mesmo estando sob a égide doutrinária do positi-vismo. Logo, isso deve ser levado em consideração no momento da análise. Porém, nesse aspecto, a dificuldade é imensa, pois recai a interpretação do teórico e do analista do teórico sobre a concepção basilar da teoria em questão.

O caminho foi desenhado em face dessas considerações. O olhar sobre o positivismo jurídico se justifica na medida em que se reconhecem as bases teóricas denominadas como tais. Significa desvelar e distinguir conceitos, teorias e doutrinas ligadas, direta ou indiretamente, a essa corrente. Claro que, para atingir os objetivos do trabalho, necessitou-se de um breve olhar sobre a teoria. Este trabalho de escavação buscou encontrar a base kelseniana e diferenciála de outras correntes/autores.

Em outro plano da exposição, buscou-se fornecer algumas visões de Kelsen e de outros autores sobre a Teoria Pura do Direito. Não se trata de crítica ou elogio, mas de convocar outras perspectivas para encarar o mesmo objeto em exame: o positivismo kelseniano. Esses juristas e textos foram invocados devido à disponibilidade bibliográfica e à forma como 
se colocam diante de Kelsen. Isso implica que tais controvérsias são apenas ilustrativas, a não ser naqueles textos referentes diretamente aos autores e às teorias, como é o caso dos artigos do próprio Kelsen e Castanheira Neves. Embora neste último autor, o texto abranja mais a sua própria idéia do que a kelseniana, nem por isso deixa de formar um diálogo com o austríaco. Em outros dois tópicos, está-se diante de uma visão de um terceiro sobre dois autores Kelsen e Cossio e Kelsen e Ortega y Gasset. Por último, Kelsen desenvolve críticas ao Ross. A intenção da última parte era trazer alguns elementos novos ou, pelo menos, não tão difundidos - não se encontram nas bibliografias consultadas, salvo aquela expressamente indicada no texto - para análise do positivismo kelseniano. Isso também significa obter do austríaco, explicações mais detalhadas da sua teoria e da Weltanschauung jurídica.

Salienta-se, por último, devido à̀ infinidade de material existente sobre o autor e sobre o positivismo, que as escolhas aqui feitas dizem respeito ao material disponivel e, além de tudo, configuram bibliografias relevantes para esta temática, embora se possa divergir da opinião dos respectivos autores, inclusive a do autor deste estudo.

\section{Referências}

BARZOTTO, Luis Fernando. O Positivismo Juridico Contemporâneo, uma introduçäo a Kelsen, Rosse Hart 2. ed. Porto Alegre: Livrania do Advogado, 2007.

BOBEIO, Norberto. O positivismo juridico. Liçóes de filosofia do Direito. Trad. Márcio Pugliesi; Edson Bini; Carlos E. Rodrigues. São Paulo: Ícone, 1995.

KAUFMANN, Arthur. Filosofia do direito. Trad. António Ulisses Contês, Lisboa: Fundação Calouste Gulbenkian, 2004.

KELSEN, Hans. Eine Grundlegung der Rechtssoziologie. In: ASWP, Band: 39, Heft 1. Tübingen: Paul Siebeck, 1914. p. 839-876.

Eine "Realistische" und die Reine Rechtslehre. Bemerkungen zu Alf Ross: On Law and Justice. In: Osterraichshe Zeitschrift für offentliches Recht. Band X. Wien, Springer, 1959/1960. p. 1-25. 
LARENZ, Karl Metodologia da ciência do direito. 3. ed. Trad. José Lamego. Lisboa: Fundaçāo Calouste Gulbenkian, 1997.

LÉVY-BRUHL, Henri. Sociologia do direito. Trad. Antonio de Pádua Danesi. 2. ed. Sấo Paulo: Martins Fontes, 2000.

LLANO ALONSO, Femando H. Las glosas de Jósé Ortega y Gasset a Hans Kelsen. In: Rivista Internazionale di Filosofia del Diritto. s. V, anno LXXXIII, n. 3 - luglio/settembre. Milano: Guuffrè, 2006. p. 407-434.

LUHMANN, Niklas. Das Recht der Gesellschaft. Frankfurt am Main: Suhrkamp, 1995.

Sociologia do direito 1. Trad. Gustavo Bayer. Rio de Janeiro: Tempo Brasileiro, 1983.

MONCADA, Luís Cabral de. Estudos de Filosofia do Direito e do Estado. v. II. Lisboa: Imprensa Nacional-Casa da Moeda, 2004.

NEVES, António Castanheira. A unidade do sistema jurídico: o seu problema e o seu sentido (diálogo com Kelsen). In: Digesta. Escritos acerca do Direito, do Pensamento Jurídico, da sua Metodologia e Outros. V. 2. Coimbra: Coimbra Editora, 1995.

PERELMAN, Chaim Lógica jurídica. Trad. Verginia K. Pupi. Sảo Paulo: Martins Fontes, 1998.

RADBRUCH, Gustav. Filosofia do direito. Trad. L. Cabral de Moncada. 6. ed. Coimbra: Arménio Amado, 1997.

REALE, Giovanni e ANTISERI, Dario. História da Filosofia. v. 3. 7 ed. São Paulo: Paulus, 2005.

REALE, Miguel. Fundamentos do direito. 3. ed São Paulo: RT, 1998.

SALDANHA, Nelson. Filosofia do direito. Rio de Janeiro: Renovar: 1998.

WELZEL, Hans Introducción a la Filosofia del Derecho. Derecho Natural e Justicia Material: Trad. Felipe Gonzáles Vicen. Buenos Aires-Montevideo, IB de F, 2005.

ZIPPELIUS, Reinhold. Das Wesen des Rechts. Eine Einführung in die Rechtsphilosophie. 3. Auflag. München: Beck, 1973. 